\title{
De shockschadevordering in het strafproces
}

\author{
Mr. E.S. Engelhard, mr. M.R. Hebly en \\ mr.drs. I. van der Zalm*
}

\begin{abstract}
1. Inleiding
Bij ernstige misdrijven, zoals moord en doodslag, komt het met regelmaat voor dat naasten en nabestaanden van slachtoffers op schadelijke wijze worden geconfronteerd met het misdrijf of de gevolgen ervan. Naar civiel recht bestaat dan mogelijk een aanspraak op vergoeding van de (psychische) schade die zij door de confrontatie met de schokkende gebeurtenis lijden. Willen zij hun schade verhalen, dan hebben zij in beginsel de mogelijkheid om zich met hun shockschadevordering als benadeelde partij te voegen in het strafproces, maar tot voor kort overwoog de Hoge Raad nog expliciet dat een dergelijke vordering 'niet van zo eenvoudige aard' is dat zij zich leent voor behandeling in het strafgeding. Een pijnlijke tegenstelling dus: misdrijven als moord en doodslag die bij uitstek in het strafproces 'thuishoren', leiden met regelmaat tot shockschade bij naasten, waarvoor de dader naar civiel recht ook aansprakelijk is, maar tegelijkertijd suggereert de rechtspraak dat de vordering tot schadevergoeding zich in het algemeen niet zou lenen voor behandeling in het strafproces. Niet-ontvankelijkverklaring door de strafrechter lijkt doorgaans nul op het rekest te betekenen, nu de burgerrechtelijke route de benadeelde partij niet alleen procedureel meer belast, maar vanwege de onverzekerbaarheid van geweldsmisdrijven ook weinig uitzicht biedt op daadwerkelijk verhaal. ${ }^{1}$ Weliswaar is per 1 januari 2011 het voegingscriterium verruimd - het gaat nu om de vraag of de behandeling van de vordering van de benadeelde partij niet een onevenredige belasting van het strafgeding ople-
\end{abstract}

Mr. E.S. Engelhard is promovendus bij de sectie Burgerlijk Recht van Erasmus School of Law, Erasmus University Rotterdam. Mr. M.R. Hebly is promovendus bij de sectie Burgerlijk Recht van Erasmus School of Law, Erasmus University Rotterdam. Mr. drs. I. van der Zalm is wetenschappelijk docent bij de sectie Burgerlijk Recht van Erasmus School of Law, Erasmus University Rotterdam. De auteurs danken de studentassistenten Melissa de Groot en Rosalie Dieleman voor hun assistentie bij het jurisprudentieonderzoek.

1. Onverminderd de gevallen waarin sprake is van een solvente dader en de gevallen waarin de benadeelde bij de civiele rechter zelfs geholpen kan zijn bij een strafrechtelijke veroordeling van de dader. Dat slachtoffers van strafbare feiten schaars zijn in het civiele recht - al heeft dat niet alleen betrekking op de shockschadevordering, maar breder bekeken blijkt uit W.M. Schrama \& T. Geurts, Civiel schadeverhaal door slachtoffers van strafbare feiten, Den Haag: WODC 2012, p. 108, en zie voor ervaringen van die slachtoffers J.D.M. van Dongen, M.R. Hebly \& S.D. Lindenbergh, 'Je hebt geluk als je van een pauw mag plukken.' Ervaringen van slachtoffers van strafbare feiten met het verhaal van schade, Den Haag: WODC 2013. vert - maar het is niet duidelijk in hoeverre dit ook gevolgen heeft voor de mate waarin shockschadevorderingen door strafrechters inhoudelijk worden beoordeeld.

In dit artikel staat daarom de volgende vraag centraal:

In hoeverre verklaren strafrechters benadeelden in bun shockschadevordering - in lijn met wat de rechtspraak van de Hoge Raad suggereert - niet-ontvankelijk, en in hoeverre worden deze vorderingen wel behandeld in het strafproces?

Eerder is reeds gesuggereerd dat strafrechters geneigd zijn om een vordering tot vergoeding van shockschade in het strafproces toe te wijzen, zolang die vordering niet wordt betwist en deze voldoende is onderbouwd (doorgaans met een medische verklaring ten aanzien van het bestaan van geestelijk letsel). ${ }^{2}$ Vervolgens rijst de vraag welke vorderingen wel en welke vorderingen geen schipbreuk lijden op de ontvankelijkheidstoets van het strafproces, en of uit die uitspraken valt af te leiden welke factoren daarbij (steeds) een rol spelen.

Om deze vragen te beantwoorden is uitvoerig jurisprudentieonderzoek verricht, waarbij allereerst in 'kwantitatief opzicht is vastgesteld hoeveel gevoegde shockschadevorderingen bij benadering (al dan niet deels) worden toe- of afgewezen in het strafproces, en hoe vaak de strafrechter de benadeelde in deze vordering niet-ontvankelijk verklaart. Vervolgens zijn de uitspraken meer 'kwalitatief bestudeerd om te achterhalen welke factoren bepalend zijn voor het 'lot' van de shockschadevordering in het strafproces.

In dit artikel zullen eerst de achtergronden van dit onderzoek worden geschetst (par. 2). Vervolgens zal de methode van onderzoek worden toegelicht (par. 3), waarna de resultaten en bevindingen worden weergegeven (par. 4) en tot slot geëvalueerd (par. 5).

2. Zie M.R. Hebly, JA 2015/43, annotatie bij Rb. Noord-Nederland 30 maart 2015, ECLI:NL:RBNNE:2015:507 (m.n. voetnoot 14), die een korte verkenning doet. Zie reeds eerder de conclusie van P-G Bleichrodt voor HR 3 juli 2007, RvdW 2007/709, onder 5.16. 


\section{Achtergrond}

\subsection{Voeging in het strafproces}

De afgelopen jaren wordt in toenemende mate aandacht besteed aan herstel via schadevergoeding voor slachtoffers van strafbare feiten. Deze slachtoffers hebben de afgelopen jaren een sterkere positie gekregen in het strafproces, en de inzet van het kabinetsbeleid is om daders vaker een vergoeding te laten betalen voor de door hen aangerichte schade. ${ }^{3}$ Kernprobleem hierbij is echter dat het strafproces niet primair is ingericht op slachtofferherstel en dat de mogelijkheid om te voegen als benadeelde partij (hij die rechtstreeks schade heeft geleden door een strafbaar feit) daarom ook maar beperkt is. Wel is deze mogelijkheid recentelijk verruimd: waar voorheen de vordering van de benadeelde 'eenvoudig van aard' diende te zijn, geldt sinds 1 januari 2011 dat de vordering van de benadeelde die zich op grond van artikel $51 \mathrm{f}$ van het Wetboek van Strafvordering $(\mathrm{Sv})$ voegt in het strafproces 'geen onevenredige belasting van de strafrechtelijke procedure' mag opleveren. ${ }^{4}$ Deze wijziging had uitdrukkelijk tot doel de strafrechter vaker (en zo veel als mogelijk) inhoudelijk over de vordering van de benadeelde partij te laten beslissen. ${ }^{5}$

Het belang van slachtoffers bij oplegging van de schadevergoedingsmaatregel in het strafproces is groot: wanneer de strafrechter de schadevergoedingsmaatregel oplegt, geschiedt de inning immers door het Centraal Justitieel Incassobureau (CJIB). Bovendien geldt ten aanzien van ernstige gewelds- en zedenmisdrijven de voorschotregeling, op grond waarvan de overheid het bedrag aan schadevergoeding aan het slachtoffer uitkeert voor zover dit na acht maanden nog niet (volledig) is voldaan. ${ }^{6}$ Daarmee komt de betalingsverplichting van de veroordeelde niet te vervallen, maar is het verhaalsrisico wel verlegd naar de Staat. Men zou kunnen zeggen dat daarmee in feite voor benadeelden de leemte wordt opgevuld die bestaat daar waar aansprakelijkheidsverzekeraars doorgaans geen dekking (mogen) verlenen voor schade veroorzaakt door opzetdelicten. ${ }^{7}$ Het strafproces is daarom voor benadeelden een 'aantrekkelijke schadeverhaalsroute', zo niet een 'last resort'

3. Zie voor deze beleidslijn van het kabinet <www.rijksoverheid.nl/ onderwerpen/slachtofferbeleid $>$ en de aldaar te vinden documentatie.

4. Zie over het nieuwe ontvankelijkheidscriterium bijv. J. Candido, De vordering van benadeelde partij in het strafproces en de onevenredige belasting van het strafgeding, Trema 2011, afl. 10, p. 354-359.

5. Kamerstukken II 2007/08, 30143, 16, p. 1.

6. Dit geldt ten aanzien van maatregelen die op of na 1 januari 2011 onherroepelijk zijn geworden, zie nader Stb. 2010, 1. De voorschotregeling wordt verder uitgewerkt in het Uitvoeringsbesluit voorschot schadevergoedingsmaatregel (Stb. 2011,311) en de Beleidsbeslissing houdende een uitbreiding van de voorschotregeling (Stcrt. 2 december 2011, 21994). De voorschotregeling kent geen maximumbedrag en zal in 2016 worden uitgebreid naar alle delicten, met voor die overige delicten een maximumbedrag van $€ 5.000$, zo blijkt uit het visiedocument 'Recht doen aan slachtoffers', p. 23. Zie de bijlage bij Kamerstukken II 2012/13, 33552, 2. Sinds 2014 heeft het slachtoffer overigens op grond van art. 94a Sv de mogelijkheid conservatoir beslag te leggen op het vermogen van de dader ingeval de voorschotregeling niet van toepassing is.

7. Zie op dit punt nader N. Frenk (postume publicatie), Strafbare feiten en de reikwijdte van de opzetclausule in aansprakelijkheidsverzekeringen, VR 2015/36. voor enige financiële compensatie. ${ }^{8}$ Dat geldt in bijzondere mate voor slachtoffers van fysiek en psychisch letsel. ${ }^{9}$

\subsection{De shockschadevordering}

De vordering tot het vergoeden van schade als gevolg van een schokkende gebeurtenis is complex. Ten eerste betreft het een uitzondering op ons stelsel, waar derden - niet zijnde het primaire slachtoffer - in beginsel geen recht hebben op schadevergoeding. ${ }^{10}$ Daarnaast zijn de vereisten waaraan dient te zijn voldaan strikt en bestaat over de toepassing daarvan discussie. ${ }^{11} \mathrm{Bij}$ het instellen van een vordering tot vergoeding van shockschade dient de benadeelde aan te tonen dat - kort samengevat - sprake is van overtreding van een veiligheids- of verkeersnorm als gevolg waarvan een ernstig ongeval is veroorzaakt en hij geestelijk letsel heeft opgelopen door directe confrontatie met de gevolgen van deze gebeurtenis, hetgeen zich voornamelijk zal kunnen voordoen indien iemand tot wie benadeelde in een nauwe affectieve relatie staat, bij het ongeval is gedood of gewond. ${ }^{12}$ De Hoge Raad overweegt daarbij dat het geestelijk letsel in rechte dient te kunnen worden vastgesteld, wat in het algemeen slechts het geval is indien sprake is van een in de psychiatrie erkend ziektebeeld. ${ }^{13}$ Voornamelijk met betrekking tot de toepassing van het vereiste van directe confrontatie bestaat discussie in de literatuur en laat ook de rechtspraak zien dat de grenzen niet scherp zijn. ${ }^{14}$

\subsection{De shockschadevordering in het strafproces}

Niet zelden voegen zich als benadeelde partij in het strafproces personen met een vordering tot vergoeding van shockschade wegens het directe waarnemen van een misdrijf of de ernstige gevolgen daarvan. De Hoge Raad overweegt echter in 2003 (en opnieuw in 2007) dat de shockschadevordering door de rechter niet-ontvankelijk dient te worden verklaard, omdat deze niet van zo eenvoudige aard is dat zij zich leent voor

8. Uiteraard biedt het Schadefonds Geweldsmisdrijven tot op zekere hoogte een 'vangnet', maar het gaat daarbij om een financiële tegemoetkoming en niet om daadwerkelijke vergoeding van schade, laat staan een volledige vergoeding.

9. S.D. Lindenbergh, De letselschadevordering in het strafproces, NJB 2014/38, p. 2696-2702.

10. Zie meer in het algemeen over dit gesloten stelsel S.D. Lindenbergh \& I. van der Zalm, Schadevergoeding: personenschade (Mon. BW, deel B37), Deventer: Wolters Kluwer 2015, hoofdstuk III en voor een onderzoek naar de eventuele aanpassingen daarvan R. Rijnhout, Schadevergoeding voor derden in personenschadezaken (diss. Utrecht), Den Haag: Boom Juridische uitgevers 2012 .

11. Zie voor een (recent) overzicht op dit punt R.J.P. Kottenhagen, Vergoeding van shockschade: een update, L\&S 2015, afl. 2, p. 43-49.

12. HR 22 februari 2002, ECLI:NL:HR:2002:AD5356, NJ 2002/240 m.nt. J.B.M. Vranken (Taxibus), r.o. 4.3.

13. HR 22 februari 2002, ECLI:NL:HR:2002:AD5356, NJ 2002/240 m.nt. J.B.M. Vranken (Taxibus), r.o. 4.3. Engelhard en Engelhard gaan nader op het vereiste van een psychisch erkend ziektebeeld in en stellen dat dit vereiste niet zonder meer bruikbaar is voor het beoordelen van schadeclaims: E.F.D. Engelhard \& I.M. Engelhard, Shockschade, in: W.H. van Boom, I. Giesen \& A.J. Verheij (red.), Capita civilologie, Den Haag: Boom Juridische uitgevers 2013, p. 517-540.

14. Zie bijv. Hof Arnhem-Leeuwarden 16 december 2014 ECLI:NL:GHARL:2014:9440, JA 2015/42 m.nt. I. van der Zalm en Rb. Noord-Nederland 11 februari 2015, ELCI:NL:RBNNE:2015:507, JA 2015/43 m.nt. M.R. Hebly. Zie recent Kottenhagen 2015. 
behandeling in het strafproces. ${ }^{15}$ Ook na de invoering van het ruimere voegingscriterium in 2011 overweegt de Hoge Raad - onder verwijzing naar zijn eerdere rechtspraak - dat het oordeel van het hof (niet-ontvankelijkverklaring van een smartengeldvordering wegens shockschade omdat deze een onevenredige belasting van het strafgeding zou opleveren) niet onbegrijpelijk is, gelet op de vereisten die voor het toekennen van een dergelijke vordering gelden:

'Het Hof heeft de niet-ontvankelijkverklaring gegrond op zijn oordeel dat de behandeling van de desbetreffende vordering een onevenredige belasting van het strafgeding oplevert. Daarbij heeft het Hof in het bijzonder in aanmerking genomen dat de rechtsvraag of de verdachte naar burgerlijk recht aansprakelijk is voor de door de benadeelde partij geleden immateriële schade niet eenvoudig te beoordelen valt. Dit oordeel is niet onbegrijpelijk in aanmerking genomen dat voor vergoeding van immateriële schade als hier gevorderd, is vereist dat het bestaan van geestelijk letsel waardoor iemand in zijn persoon is aangetast, in rechte kan worden vastgesteld, hetgeen in het algemeen slechts het geval zal zijn indien sprake is van een in de psychiatrie erkend ziektebeeld (...).'16

De Hoge Raad overweegt niet opnieuw met zoveel woorden dat shockschadevorderingen in het strafproces per definitie niet-ontvankelijk dienen te worden verklaard, maar benadrukt hier - ten tijde van het wijzen van dit arrest was het nieuwe voegingscriterium ingevoerd - slechts dat dit oordeel aan de feitenrechter is. ${ }^{17}$

\section{Methode van jurisprudentieonderzoek}

Zoals hiervoor is beschreven, staat in dit artikel de vraag centraal in hoeverre shockschadevorderingen worden 'opgepakt' in het strafproces - dat door de behandeling van die vordering immers niet onevenredig mag worden belast. Om die vraag te beantwoorden is jurisprudentieonderzoek uitgevoerd, waarvoor het databestand van rechtspraak.nl is geraadpleegd. Daartoe zijn de zoektermen 'shockschade' en 'schokschade' gebezigd en is gezocht naar uitspraken van rechtbanken, gerechtshoven en de Hoge Raad binnen de sector strafrecht. ${ }^{18}$ Dat leverde na correctie 229 (gepubliceerde) uitspraken op in de

15. HR 15 april 2003, ECLI:NL:HR:2003:AF5257, r.o. 5.7 en HR 10 april 2007, ECLI:NL:HR:2007:AZ5670, r.o. 4.5.

16. HR 11 maart 2014, ECLI:NL:HR:2014:528, r.o. 4.4. Voor de uitspraak in lagere instantie, zie Hof 's-Hertogenbosch 6 april 2012, ECLI:NL:GHSHE:2012:BW1100.

17. Zie hierover nader M.R. Hebly, JA 2015/43, annotatie bij Rb. NoordNederland 30 maart 2015, ECLI:NL:RBNNE:2015:507 (m.n. voetnoot 14).

18. Naast de genoemde zoektermen is tevens gezocht met de zoektermen 'directe confrontatie', 'taxibus', 'ECLI:NL:HR:2002:AD5356', 'HR 22 februari 2002' en 'AD5356'. De resultaten waren ofwel overweldigend (duizenden), al opgenomen in de zoekresultaten van de termen 'shockschade' en 'schokschade' of niet relevant. periode april 2000 tot en met september 2015. ${ }^{19}$ Vervolgens zijn deze uitspraken geïnventariseerd en is per zaak een aantal gegevens geregistreerd, namelijk de datum van de uitspraak, de instantie, het ECLI-nummer, het aan de verdachte ten laste gelegde feit (als gevolg waarvan de vergoeding van shockschade wordt gevorderd) en de beslissing van de rechter. De mogelijke beslissingen zijn gecodeerd, te weten: niet-ontvankelijkverklaring (1), geheel of gedeeltelijke toewijzing van de vordering (2) en afwijzing van de vordering (3). ${ }^{20}$ Daarnaast is bij een nietontvankelijkverklaring de reden daarvoor opgenomen, zoals vrijspraak van de verdachte, onvoldoende onderbouwing van de vordering of de onevenredige belasting van het strafproces die de behandeling van de shockschadevordering zou opleveren. Bovendien is onderscheid gemaakt naar het geldende voegingscriterium in de periode tot 1 januari 2011 (vorderingen dienden 'eenvoudig van aard' te zijn) en de periode daarna (waarin de vordering geen 'onevenredige belasting van de strafrechtelijke procedure’ mag opleveren).

\section{Resultaten en bevindingen}

\subsection{Hoeveelheid toewijzingen, afwijzingen en niet- ontvankelijkverklaringen; een eerste analyse}

De 229 geanalyseerde uitspraken zien vrijwel allemaal op levensdelicten of andere delicten met de dood tot gevolg. ${ }^{21}$ In deze uitspraken zijn door strafrechters 361 beslissingen genomen op vorderingen tot vergoeding van shockschade, bestaande uit 260 niet-ontvankelijkverklaringen (72\%), 86 (gedeeltelijke) toewijzingen $(23,8 \%)$ en 15 volledige afwijzingen $(4,2 \%)$ (zie figuur 1 op de volgende pagina).

Dat het merendeel van de vorderingen niet-ontvankelijk wordt verklaard, ligt gezien de overwegingen die de Hoge Raad aan dit onderwerp heeft gewijd - vanwege de complexe aard van de vordering zou deze zich immers per definitie niet lenen voor behandeling in het strafgeding - in de lijn der verwachting. Het is opvallend dat desondanks bijna een kwart van alle vorderingen geheel of gedeeltelijk wordt toegewezen,

19. De zoekterm 'shockschade' leverde 243 gepubliceerde uitspraken op, de zoekterm 'schokschade' 15. Dit aantal is gecorrigeerd door het aantal overlappende uitspraken van de twee zoektermen te filteren, evenals conclusies. Uiteindelijk is het aantal resultaten gecorrigeerd naar 229 uitspraken. De auteurs zijn zich ervan bewust dat de resultaten van dit onderzoek niet volledig representatief zijn, omdat het onderzoek slechts ziet op gepubliceerde uitspraken. Desondanks zijn de resultaten (op zijn minst) illustratief voor het lot van vorderingen tot vergoeding van shockschade in het strafproces in het algemeen.

20. Aanvankelijk werden de volledige en gedeeltelijke toewijzingen als aparte categorieën opgenomen. Gelet op het kleine aantal volledige toewijzingen is er echter voor gekozen deze categorie samen te voegen met de gedeeltelijke toewijzingen.

21. Zoals brandstichting, de dood tot gevolg hebbende (art. $157 \mathrm{Sr}$ ), diefstal met geweldpleging de dood ten gevolge (art. 312 lid $3 \mathrm{Sr}$ ) en aanmerkelijk onvoorzichtig rijgedrag de dood ten gevolge (art. 6 WVW 1994). In slechts een handjevol zaken werd aan de dader een ander strafbaar feit ten laste gelegd, namelijk grafschennis (art. $149 \mathrm{Sr}$ ), diefstal (art. $310 \mathrm{Sr}$ ), kinderpornografie (art. 240b Sr) en verkrachting (art. $242 \mathrm{Sr}$ ), hoewel dat laatste delict slechts voorkomt in combinatie met moord of doodslag. 


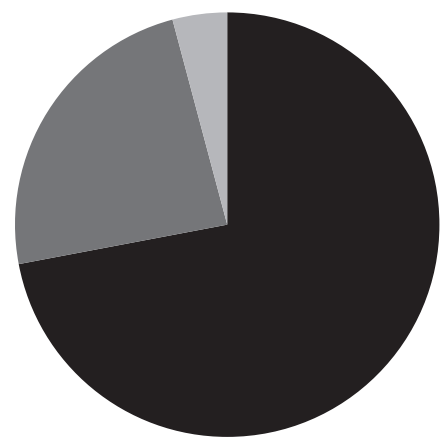

- Niet-ontvankelijk $\square$ Gehele/gedeeltelijke toewijzing $\quad$ Afwijzing

Figuur 2 Procentuele verhouding beslissingen voor en na 1 januari 2011

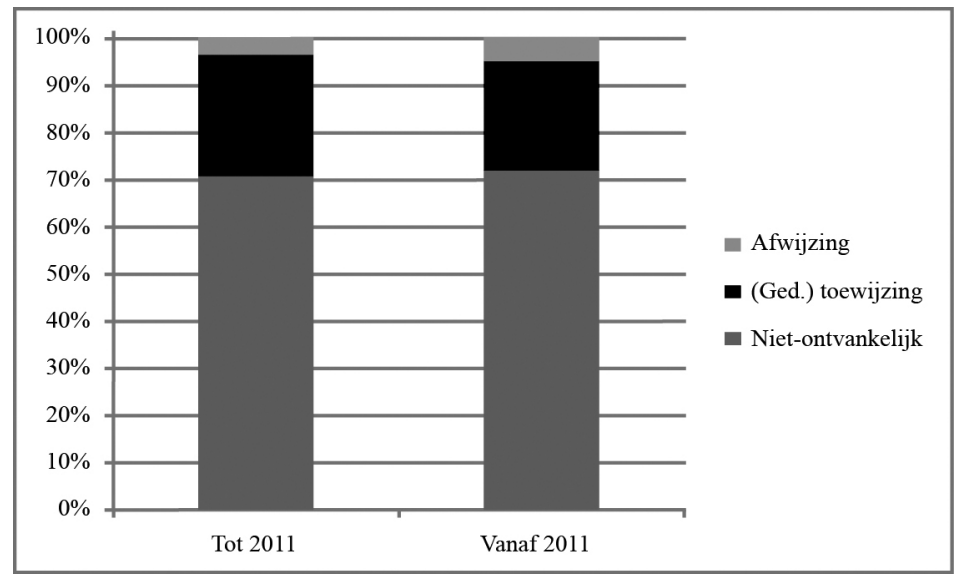

en daarmee binnen het strafgeding wél inhoudelijk wordt behandeld door de strafrechter.

Tevens is bezien of met het nieuwe voegingscriterium per 1 januari 2011 - waarmee een verruiming werd beoogd - verhoudingsgewijs meer shockschadevorderingen zijn behandeld door de strafrechter. In het algemeen zou men daarna een afname van het aantal niet-ontvankelijkverklaringen mogen verwachten (immers, vorderingen die voorheen schipbreuk leden omdat zij niet van eenvoudige aard waren, zouden nu door de strafrechter kunnen worden behandeld, zolang zij geen onevenredige belasting van het strafproces vormen). Uit onze rechtspraakanalyse valt echter geen afname van het relatieve aantal niet-ontvankelijkverklaringen ten aanzien van shockschadevorderingen af te leiden: er lijkt geen verandering te zijn opgetreden per 2011 (zie figuur 2).

Om meer inzicht te verkrijgen in de redenen van strafrechters om tot een bepaalde beslissing te komen, zijn de motiveringen door middel van een meer 'kwalitatieve' bestudering van de uitspraken nader onderzocht. In de volgende paragrafen wordt per categorie - niet-ontvankelijkverklaringen (par. 4.2), gehele of gedeeltelijke toewijzingen (par. 4.3) en afwijzingen (par. 4.4) - verslag gedaan van de resultaten en bevindingen.

\subsection{Nadere analyse niet-ontvankelijkverklaringen}

\subsubsection{Motivering en redenen niet- ontvankelijkverklaringen}

Om te achterhalen om welke redenen de vorderingen van benadeelde partijen tot vergoeding van shockschade niet-ontvankelijk zijn verklaard, zijn de betreffende 260 beslissingen nader bestudeerd. Omdat veel van de daarin neergelegde motiveringen uitblinken in beknoptheid, bleek dat geen eenvoudige taak. Een voorbeeld van een dergelijke beknoptheid is de overweging in een arrest van het Hof Den Haag uit 2011:

'De behandeling van de vordering van de benadeelde partij dat betrekking heeft op de immateriële kosten (shockschade) levert naar het oordeel van het hof een onevenredige belasting van het strafgeding op. Het hof zal dan ook bepalen dat de benadeelde partij voor dat deel niet-ontvankelijk is in de vordering. ${ }^{, 22}$

22. Hof Den Haag 21 november 2011, ECLI:NL:GHSGR:2011:BU5110. Uiteraard zijn er meer voorbeelden te vinden van een dergelijke (zeer) beknopte motivering, maar door het zeer grote aantal niet-ontvankelijkverklaringen is ervoor gekozen in par. 4.2 slechts illustrerende uitspraken aan te halen. 
Een nog beknopter voorbeeld betreft de overweging uit de uitspraak van de Rechtbank Utrecht uit 2009:

'De rechtbank acht de shockschade voor de overige gezinsleden onvoldoende eenvoudig vast te stellen. ${ }^{.23}$

Hoewel een aantal rechters weliswaar meer woorden wijdt aan de overweging om de benadeelde partij in de shockschadevordering niet-ontvankelijk te verklaren, blijft het vaak gissen waarom in het concrete geval niet-ontvankelijkverklaring volgt, en, wanneer wordt overwogen dat de behandeling van de shockschadevordering een onevenredige belasting voor het strafgeding vormt, waar die onevenredigheid dan precies in schuilt. $^{24}$

Een belangrijke bevinding is dan ook dat niet-ontvankelijkverklaringen door strafrechters weinig inzichtelijk in uitspraken worden gemotiveerd. Ons inziens kan niet met de algemene constatering worden volstaan dat het bij shockschadevorderingen zou gaan om een juridisch en feitelijk gecompliceerde schadevergoedingskwestie en dat daarom de beoordeling ervan een onevenredige belasting van het strafproces oplevert. Gezien de grote belangen van de benadeelde partij bij de inhoudelijke beslissing op diens vordering, zou de strafrechter ons inziens inzichtelijk(er) moeten maken waarom hij in dit concrete geval niet tot een behandeling van de vordering overgaat. Wij komen hier later op terug.

Ondanks het voorgaande zijn wij tot een zekere categorisering gekomen van de overwegingen die strafrechters ten grondslag leggen aan hun beslissingen om benadeelden in hun shockschadevorderingen niet-ontvankelijk te verklaren. De uitspraken zijn ondergebracht in zes categorieën, te weten: (1) niet voldaan aan de vereisten uit het Taxibus-arrest, (2) onevenredig belastend of niet eenvoudig van aard vanwege het gecompliceerde karakter van de vordering, (3) onevenredig belastend of niet eenvoudig van aard vanwege het ontbreken of onvoldoende onderbouwing van de vordering, (4) onevenredig belastend of niet eenvoudig van aard, niet nader gemotiveerd, (5) onvoldoende onderbouwing van de vordering of (6) een overige reden. ${ }^{25}$ In figuur 3 (zie volgende pagina) wordt weergegeven hoe vaak deze overwegingen terug te lezen zijn in de uitspraken.

Uit figuur 3 blijkt dat er doorgaans twee overwegingen worden gegeven op grond waarvan verreweg de meeste vorderin-

23. Rb. Utrecht 4 augustus 2009, ECLI:NL:RBUTR:2009:BJ4492.

24. Een voorbeeld is de uitspraak van de Rechtbank Rotterdam uit 2013: Rb. Rotterdam 25 juli 2013, ECLI:NL:RBROT:2013:5762.

25. Hoewel deze categorisering wellicht wat geforceerd aandoet, is volgens ons door de (zeer) summiere motivering van niet-ontvankelijkverklaring een andere indeling niet mogelijk. Veel beslissingen lieten zich door hun beknopte motivering moeilijk categoriseren, en het proces van categorisering is daardoor in meerdere mate afhankelijk geworden van de 'subjectieve' lezing van de auteurs van wat als 'primaire' reden uit de uitspraak naar voren komt: er zijn nu eenmaal grensgevallen die in meer dan één categorie hadden kunnen worden geplaatst. gen tot vergoeding van shockschade (228 van de 260) nietontvankelijk worden verklaard. Enerzijds werd in 115 gevallen door de strafrechter geoordeeld dat niet was voldaan aan de vereisten die door de Hoge Raad aan een shockschadevordering zijn gesteld in het Taxibus-arrest. ${ }^{26}$ In verreweg de meeste gevallen (99 van de 115) was er geen sprake van een in de psychiatrie erkend ziektebeeld of werd het bestaan hiervan door de benadeelde partij niet of onvoldoende onderbouwd. In de overige 16 zaken was er volgens de strafrechter geen sprake van het waarnemen van of een directe confrontatie met (de gevolgen van) het dodelijke ongeval. Anderzijds vormde de vordering van de benadeelde partij in 113 gevallen een onevenredige belasting voor het strafgeding of was deze niet van zodanig eenvoudige aard dat zij zich leende voor behandeling in het strafproces. In deze categorie werd de niet-ontvankelijkverklaring om drie redenen uitgesproken: vanwege het gecompliceerde karakter van de shockschadevordering in het algemeen (72 van de 113), vanwege onvoldoende onderbouwing van de vordering of het geheel ontbreken van een onderbouwing $(27$ van de 113), of de vordering was niet van eenvoudige aard of vormde een onevenredige belasting van het strafgeding zonder enige nadere motivering (14 van de 113).

Overigens is niet uitgesloten dat afwijzing van de vordering tot vergoeding van shockschade in sommige gevallen meer voor de hand zou liggen: zo worden 13 shockschadevorderingen nietontvankelijk verklaard omdat deze onvoldoende onderbouwd zijn en stranden andere vorderingen omdat niet is voldaan aan een van de vereisten uit het Taxibus-arrest. ${ }^{27}$

\subsubsection{Shockschade 'lezen' in een smartengeldvordering}

Uit de geanalyseerde niet-ontvankelijkverklaringen blijkt dat door de benadeelde partij niet zelden een vergoeding van immateriële schade wordt gevorderd, zonder nader te specificeren wat hiervan de grondslag is of waar die immateriële schade precies in gelegen is. De strafrechter 'leest' hierin vervolgens - na ook op de mogelijkheden tot vergoeding van affectieschade en het bestaan van een oogmerk als bedoeld in artikel 6:106 lid 1 sub a van het Burgerlijk Wetboek (BW) in te zijn gegaan - een vordering tot vergoeding van shockschade. Het ontbreekt deze vorderingen vaak aan een (degelijke) onderbouwing, in het bijzonder ten aanzien van het bestaan van een in de psychiatrie erkend ziektebeeld bij de benadeelde partij. Dit lijkt voor de strafrechter veelal reden te zijn om de vordering van de benadeelde partij niet-ontvankelijk te verklaren. Dat blijkt bijvoorbeeld uit de uitspraak van de Rechtbank Amsterdam uit 2013:

26. HR 22 februari 2002, ECLI:NL:HR:2002:AD5356, NJ 2002/240 m.nt. J.B.M. Vranken (Taxibus).

27. Dit lijkt evengoed te gelden voor de 27 vorderingen die niet-ontvankelijk worden verklaard, omdat zij vanwege onvoldoende onderbouwing een onevenredige belasting van het strafproces zouden opleveren of niet van zodanig eenvoudige aard zijn dat zij zich lenen voor behandeling in het strafproces. 
Figuur 3 Redenen niet-ontvankelijkverklaring shockschadevordering*

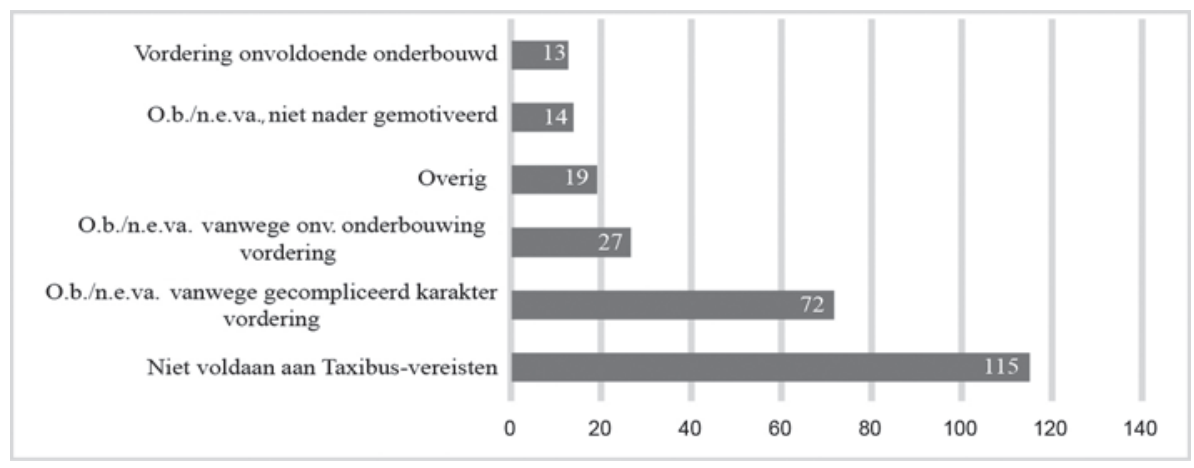

'De (...) gevorderde $€ 10.000,-(.$.$) zou alleen op grond van$ artikel 6:106 lid 1 onder a BW toewijsbaar zijn als het (enkele) doel van het doden van [persoon 1] erin was gelegen de nabestaanden te benadelen. Met de raadsman van [verdachte] is de rechtbank van oordeel dat dat niet aannemelijk is geworden. Ook voor de stelling (...) dat het oogmerk in artikel 6:106 lid 1 onder a BW besloten ligt in de onvermijdelijkheid van het gevolg ziet de rechtbank in wettekst noch jurisprudentie aanknopingspunten. Voor zover de drievoudige vordering shockschade zou betreffen, oordeelt de rechtbank dat - bij ontbreken van onderbouwing in de vorm van psychiatrische rapportage - deze vordering een onevenredige belasting van het strafgeding oplevert. $^{28}$

\section{Zo oordeelt ook de Rechtbank Midden-Nederland in 2014:}

'Naar Nederlands recht hebben nabestaanden van een overleden slachtoffer geen mogelijkheid zich te voegen ter zake van een vordering tot affectieschade. Voor zover de vordering van de nabestaanden daarop betrekking heeft, kan die dan ook niet worden toegewezen. Voor zover die vordering ziet op een tegemoetkoming wegens shockschade oordeelt de rechtbank als volgt. In het civiele recht wordt shockschade slechts vergoed indien sprake is van werkelijk ernstig, in rechte vast te stellen geestelijk letsel die de naaste van het slachtoffer rechtstreeks is aangedaan. Daarvan zal in het algemeen slechts sprake zijn bij een in de psychiatrie erkend ziektebeeld. Uit de toelichting op de vorderingen (...) is niet van een dergelijk ziektebeeld gebleken. Reeds om die reden kunnen de vorderingen op die grond evenmin worden toegewezen. ${ }^{29}$

Deze uitspraken zijn illustratief voor de (vele) shockschadevorderingen die afstuiten op het vereiste van een in de psychiatrie erkend ziektebeeld: omdat vergoeding van immateriële schade wordt gevorderd zonder nadere grondslag, ontbreekt veelal ook de voor toewijzing van deze vordering noodzakelijke psychiatrische rapportage.

28. Rb. Amsterdam 29 januari 2013, ECLI:NL:RBAMS:2013:1291. 29. Rb. Midden-Nederland 24 april 2014, ECLI:NL:RBMNE:2014:1571.

\subsubsection{Het inherent complexe karakter van de vordering}

Een aanzienlijk deel van de vorderingen tot vergoeding van shockschade in het strafproces wordt niet-ontvankelijk verklaard vanwege de onevenredige belasting voor het strafgeding of vanwege het feit dat deze vorderingen niet zo eenvoudig van aard zijn dat zij zich lenen voor behandeling in het strafproces (113 van de 260). Het merendeel daarvan (72 van de 113) werd door de strafrechter onevenredig belastend of niet van eenvoudige aard geacht vanwege kennelijk het 'inherent complexe karakter' van de shockschadevordering in het algemeen, zo overweegt bijvoorbeeld de Rechtbank Dordrecht in 2008:

'(...) dat de benadeelde partij niet-ontvankelijk zal moeten worden verklaard in haar vordering voor zover deze immateriële schade betreft. Daar dit gedeelte betrekking heeft op shockschade is deze schade per definitie niet van zodanige eenvoudige aard dat zij zich leent voor behandeling in het strafgeding. 30

Ook na de verruiming van het voegingscriterium per 1 januari 2011 blijkt het 'complexe karakter' van de shockschadevordering in het algemeen in de weg te staan aan de behandeling ervan, zoals blijkt uit de overweging van de Rechtbank Midden-Nederland uit 2013:

'Ten aanzien van het door de benadeelde partijen gevorderde [shockschade; EE, MH \& IvdZ] is de rechtbank van oordeel dat het hier gaat om een gecompliceerde schadevergoedingskwestie, waarin een aantal civielrechtelijk ingewikkelde vragen beantwoord dient te worden. Een inhoudelijke beoordeling van de vorderingen door de rechtbank in de onderhavige strafprocedure zou een aanzienlijke vertraging en een onevenredige belasting van het strafgeding opleveren. ${ }^{31}$

Hiermee lijken strafrechters te suggereren dat de vordering tot vergoeding van shockschade zich in het algemeen niet leent

30. Rb. Dordrecht 25 april 2008, ECLI:NL:RBDOR:2008:BD0620.

31. Rb. Midden-Nederland 17 juni 2013, ECLI:NL:RBMNE: 2013:CA3375. 
voor behandeling in het strafproces. Dit verrast niet: het is in lijn met wat de rechtspraak van de Hoge Raad suggereert. ${ }^{32}$

\subsection{Nadere analyse (gedeeltelijk) toegewezen vorderingen}

\subsubsection{De vaststelling van een in de psychiatrie erkend ziektebeeld}

Het eerste wat opvalt bij het bestuderen van de (gedeeltelijke) toewijzingen, is dat verschillend wordt omgegaan met de vaststelling van een in de psychiatrie erkend ziektebeeld. In de meeste gevallen van toewijzing is een schriftelijke verklaring van een deskundige overgelegd. Toch wordt in een aantal zaken een shockschadevordering toegewezen zonder dat de strafrechter in zijn vonnis uitdrukkelijk te kennen geeft dat een in de psychiatrie erkend ziektebeeld inderdaad is vastgesteld door een deskundige. ${ }^{33}$ Vaak blijft het in die vonnissen bij de overweging dat uit het onderzoek ter terechtzitting voldoende is gebleken dat de gevoegde benadeelde partij als gevolg van het bewezenverklaarde handelen van verdachte rechtstreeks schade heeft geleden, of dat de rechter het voldoende aannemelijk acht dat de benadeelde partij immateriële schade wegens shock heeft geleden. Of er in die strafzaken daadwerkelijk een rapport of verklaring is ingebracht waaruit een in de psychiatrie erkend ziektebeeld kan worden afgeleid, blijkt dus niet uit het lezen van deze uitspraken.

Opmerkelijker zijn de uitspraken waarin strafrechters uitdrukkelijk overwegen dat voor toewijzing van de shockschadevordering geen medische verklaring nodig is ter onderbouwing van het geestelijk letsel. Een aantal daarvan zal hier kort worden besproken.

In een zaak voor het Hof Amsterdam in 2006, waarin het ging om een man die bij thuiskomst zijn dochter levenloos, in gedeeltelijk ontklede toestand, badend in het bloed als gevolg van zeer vele steekletsels aantrof, speelde de vraag of zijn shockschadevordering ondanks het ontbreken van een psychiatrische rapportage (waarvan werd verondersteld dat het opstellen ervan voor hem een psychische en financiële belasting zou vormen) kon worden toegewezen. Het hof overweegt:

'Het hof heeft zich ook zelf een beeld kunnen vormen van de omstandigheden waaronder vader zijn dochter heeft

32. HR 11 maart 2014, ECLI:NL:HR:2014:528, r.o. 4.4. Overigens overweegt de Hoge Raad ook voor de invoering van het ruimere voegingscriterium dat de shockschadevordering door de rechter niet-ontvankelijk dient te worden verklaard, omdat deze niet van zo eenvoudige aard is dat zij zich leent voor behandeling in het strafgeding, zie HR 15 april 2003 , ECLI:NL:HR:2003:AF5257, r.o. 5.7 en HR 10 april 2007, ECLI:NL:HR:2007:AZ5670, r.o. 4.5.

33. Hierbij gaat het om Rb. Arnhem 12 november 2012, ECLI:NL:RBARN: 2012:BY2835 en Rb. Arnhem 12 november 2012, FJR 2013/13 m.nt. R. de Jong, Rb. Arnhem 3 september 2012, NJ 2013/89, Rb. Arnhem 30 augustus 2011, ECLI:NL:RBARN:2011:BR6185, Rb. Utrecht 4 augustus 2009, VR 2009/120 en Rb. Den Haag 8 november 2006, NBSTRAF $2006 / 486$ aangetroffen, waarvan de diverse foto's in het dossier op schokkende wijze getuigen. Het hof is van oordeel dat het op grond van het voorgaande zo evident is dat geestelijk letsel bij de vader bestaat, waardoor hij in zijn persoon is aangetast, een en ander als gevolg van (de confrontatie met de gevolgen van) het onder 1 bewezengeachte feit (...) dat voor toekenning van het na te noemen gedeelte van de vordering dan ook geen nadere psychiatrische en/of psychologische rapportage is geboden. ${ }^{34}$

Dit arrest houdt in cassatie geen stand: de Hoge Raad casseert, nu het hof onvoldoende blijk heeft gegeven te hebben onderzocht of aan het vereiste van persoonsaantasting wegens geestelijk letsel is voldaan. ${ }^{35}$ De Hoge Raad houdt in 2007 dus strikt de hand aan de vaststelling van geestelijk letsel door middel van een verklaring van een deskundige, hoewel de noodzaak van die verklaring niet met zoveel woorden terug te lezen is in het Taxibus-arrest.

Een vergelijkbare uitspraak deed de Rechtbank 's-Hertogenbosch in 2009 in een zaak waarin het ging om doodslag van een campinghouder, nadat deze de verdachte had betrapt bij diefstal. De broer van het slachtoffer claimt vergoeding van shockschade, maar de verdediging voert aan dat er geen omschrijving wordt gegeven van het psychisch letsel dat hij door het incident heeft opgelopen. De rechtbank overweegt niettemin dat het trauma voor de broer van het overleden slachtoffer 'evident' is: de broer heeft het slachtoffer ten tijde van het misdrijf gehoord en gezien en daarna buiten de voortent zien sterven. ${ }^{36}$

In 2009 overweegt de Rechtbank Zutphen ten aanzien van de vordering van een vader wiens zoon in een café werd vermoord en die kort na de moord met het door messteken toegetakelde en gereanimeerde lichaam van zijn zoon werd geconfronteerd:

'De rechtbank acht het alleszins aannemelijk dat manier waarop [slachtoffer] om het leven is gebracht en de wijze waarop de vader hiermee geconfronteerd is vlak na het gebeurde een onmetelijk verdriet en een grote schok bij hem heeft teweeggebracht. De vader van [slachtoffer] is door de zinloze en gewelddadige dood van zijn zoon voor het leven getekend. De leegte die door het gemis van [slachtoffer] in het gezin is ontstaan zal nooit meer worden opgevuld. Gelet op het voorgaande acht de rechtbank een verklaring van een deskundige, zoals door de raadsman nodig geacht, geen toegevoegde waarde te hebben. ${ }^{37}$

34. Hof Amsterdam 24 maart 2006, ECLI:NL:GHAMS:2006:AV8220.

35. HR 3 juli 2007, NJ 2007/413, r.o. 4.3.

36. Rb. 's-Hertogenbosch 20 februari 2009, ECLI:NL:RBSHE:2009: $\mathrm{BH} 3301$. Voor zover ons bekend (ons zicht is beperkt tot de gepubliceerde rechtspraak) is tegen dit vonnis geen hoger beroep aangetekend.

37. Rb. Zutphen 13 oktober 2009, ECLI:NL:RBZUT:2009:BK0030. 
In hoger beroep houdt dit vonnis evenmin stand: zonder een schriftelijke verklaring van een deskundige en doordat de vordering door de verdediging is betwist, verklaart het hof de vordering (alsnog) niet-ontvankelijk. ${ }^{38}$

In 2010 overweegt de Rechtbank Roermond in een zaak waarin een man wordt veroordeeld voor moord op zijn dochter en voor poging tot moord op zijn zoon en waarin de moeder vergoeding van shockschade vordert:

'Alhoewel de door de benadeelde partij gestelde therapie niet aan de hand van bescheiden is gestaafd, acht de rechtbank het op grond van de aanwezige stukken aannemelijk dat de benadeelde partij deze therapie volgt. ${ }^{39}$

Tot slot vernietigt de Hoge Raad in september 2015 een arrest van het Hof Arnhem-Leeuwarden uit 2013, waarin hij overweegt dat onvoldoende is gebleken dat het hof heeft onderzocht of daadwerkelijk aan de vereisten uit het Taxibus-arrest is voldaan. ${ }^{40}$ Uit een brief van een GGZ-instelling, waaruit bleek dat sprake is van een 'heftige rouwreactie', mocht het - kennelijk - niet afleiden dat daarmee ook aan het vereiste van het bestaan van een in de psychiatrie erkend ziektebeeld is voldaan.

Deze uitspraken illustreren dat strafrechters soms geneigd zijn een persoonsaantasting wegens geestelijk letsel aan te nemen zonder een dergelijke verklaring. De Hoge Raad lijkt daarentegen echter vast te houden aan het vereiste dat een in de psychiatrie erkend ziektebeeld moet worden vastgesteld. Alle welwillendheid van lagere rechters ten spijt lijken toewijzingen zonder een medische verklaring uiteindelijk schipbreuk te lijden.

\subsubsection{Gedeeltelijke toewijzing als 'voorschot'?}

Een tweede punt dat opvalt in de (gedeeltelijke) toewijzingen is dat daaraan uitdrukkelijk een 'voorschotkarakter' wordt toegeschreven. ${ }^{41}$ Het woord 'voorschot' wordt dan uitdrukkelijk gebezigd ten aanzien van het toegewezen bedrag (doorgaans $€ 5.000$ ); voor het overige deel verklaart de rechter de benadeelde in de vordering niet-ontvankelijk. ${ }^{42}$ Zo overweegt de

38. Hof Arnhem 13 december 2010, ECLI:NL:GHARN:2010:BO7119.

39. Rb. Roermond 19 november 2010, ECLI:NL:RBROE:2010:BO4464. Deze vordering wordt in hoger beroep niet betwist, zo blijkt uit Hof 's-Hertogenbosch 26 oktober 2011, ECLI:NL:GHSHE: 2011:BU1952.

40. HR 29 september 2015, ECLI:NL:HR:2015:2858, r.o. 3.3 en 3.4.

41. Zie o.m. Rb. Dordrecht 7 juni 2002, ECLI:NL:RBDOR:2002:AE3832, Rb. Breda 20 juni 2002, ECLI:NL:RBBRE:2002:AE6845, Hof's-Hertogenbosch 3 oktober 2003, ECLI:NL:GHSHE:2003:AL6183 en Hof's-Hertogenbosch 14 juli 2005, ECLI:NL:GHSHE:2005:AT9340.

42. Dit houdt overigens geen verband met de in art. 2 van het Uitvoeringsbesluit voorschot schadevergoedingsmaatregel genoemde grens van $€ 5.000$ (die het CJIB uitkeert bij niet tijdig betaalde verplichtingen van de veroordeelde aan het slachtoffer). Deze grens geldt immers slechts ten aanzien van misdrijven niet zijnde 'ernstige gewelds- en zedenmisdrijven', terwijl de hier onderzochte gevallen van shockschade juist tot die categorie behoren.
Rechtbank Midden-Nederland in de zogenoemde 'grensrechterzaak':

'(...) dat de immateriële schade van [getuige 1], als directe waarnemer van de gebeurtenissen op 2 december 2012, valt te kwalificeren als shockschade. Hoe die schade uit te drukken valt in een geldbedrag kan, zonder dit strafproces onevenredig te belasten, niet exact worden vastgesteld. Echter, nu naar het oordeel van de rechtbank vast is komen te staan dat [getuige 1] nadelige psychische gevolgen van genoemde gebeurtenissen heeft ondervonden en nog steeds ondervindt, zal de rechtbank hem in ieder geval als voorschot een bedrag toekennen van $€ 5.000$. ${ }^{43}$

Het betreft hier uitspraken waarin uitdrukkelijk de term 'voorschot' wordt gebezigd door de rechter. De vraag is of die term goed uitdrukt wat er daadwerkelijk gebeurt. Maakt de rechter niet gewoon gebruik van zijn bevoegdheid om de vordering deels niet-ontvankelijk te verklaren en het overige dus (gedeeltelijk) toe te wijzen? Soms is het de benadeelde partij zelf die aangeeft een 'voorschot' op de immateriële schade te verlangen, maar ook dat lijkt niet meer te betekenen dan gebruikmaking van de mogelijkheid ex artikel $51 \mathrm{f} \mathrm{lid} 3 \mathrm{~Sv}$ om de vordering te splitsen en (slechts) een deel ervan te voegen wegens de complexiteit van de gehele vordering. ${ }^{44}$ Het doel daarvan zal dan zijn om in elk geval dat gedeelte van de vordering in het strafproces toegewezen te krijgen, dat met een beperkt onderzoek op de strafzitting kan worden vastgesteld (zonder het meerdere prijs te geven).

De term 'voorschot' is hier ongelukkig omdat het suggereert dat er een voorschot op een nader vast te stellen totale schadevergoeding wordt toegekend. ${ }^{45}$ Van een latere 'definitieve vaststelling' is echter geen sprake: de begroting van de omvang van de immateriële schade wegens een schokkende waarneming is hier zeker niet voorlopig, en het toegewezen (deel)bedrag aan smartengeld wordt reeds definitief zodra de uitspraak van de strafrechter hieromtrent onherroepelijk wordt. ${ }^{46}$ In letterlijke zin past het vorderen (en toewijzen) van een 'voorschot' via het strafproces dus niet binnen ons wettelijk systeem, en wanneer daarvan wel gesproken wordt, moet het in elk geval worden geïnterpreteerd als een gedeeltelijke vordering (of toewijzing). ${ }^{47}$

43. Zie Rb. Midden-Nederland 17 juni 2013, ECLI:NL:RBMNE: 2013:CA3375, ECLI:NL:RBMNE:2013:CA3397, ECLI:NL:RBMNE: 2013:CA3405, ECLI:NL:RBMNE:2013:CA3412, ECLI:NL:RBMNE: 2013:CA3420, ECLI:NL:RBMNE:2013:CA3428 en ECLI:NL: RBMNE:2013:CA3434.

44. Zo is het geval in Rb. Utrecht 13 februari 2009, ECLI:NL:RBUTR: 2009:BH2918.

45. Uit een evaluatie van de Wet Terwee blijkt dat wel vaker een vordering van de benadeelde partij bij wijze van 'voorschot' wordt toegewezen, zie R.S.B. Kool \& M. Moerings, De Wet Terwee: evaluatie van juridische knelpunten, Deventer: Gouda Quint 2001, p. 15, 44 en 46.

46. Vgl. Raad voor de rechtspraak, Aanbevelingen civiele vordering en schadevergoedingsmaatregel m.b.t. de Wet Terwee en de Wet ter versterking van de positie van het slachtoffer, Programma Strafsector, oktober 2011, p. 13-14.

47. Vgl. HR 19 maart 2002, NJ 2002/497, r.o. 4.3. 
De redenen die sommige rechters aandragen voor het toekennen van een 'voorschot' geven ook te denken. Volgens rechters zou het strafproces onevenredig worden belast indien de shockschade 'exact' in geldelijke termen moet worden vertaald, maar tegelijkertijd neemt de rechtbank het bestaan van de vordering als zodanig wél aan (anders zou in het geheel geen toewijzing moeten plaatsvinden). Dat impliceert dus dat naar het oordeel van de strafrechter weliswaar aan de vereisten voor toekenning is voldaan, maar het suggereert ook dat de strafrechter voor wat betreft de omvang van het bedrag aan smartengeld 'op safe speelt'. ${ }^{48}$ Men zou zich kunnen afvragen of de strafrechter zich hierin terecht enigszins verlegen voelt: zou het niet zo kunnen zijn dat smartengeldvorderingen wegens shock bij moord en doodslag in de praktijk veel vaker worden voorgelegd aan strafrechters dan aan civiele rechters, en wordt er dus wel terecht een grotere 'deskundigheid' op dit vlak bij de civiele rechter verondersteld? ${ }^{49}$

\subsection{Nadere analyse afgewezen vorderingen}

Een aantal vorderingen ter zake van shockschade wordt door de strafrechter afgewezen ( 15 van de bestudeerde uitspraken). In de meeste gevallen daarvan is naar het oordeel van de strafrechter niet voldaan aan het vereiste van directe confrontatie. ${ }^{50}$ Dat is opvallend, omdat we eerder zagen dat in de meeste gevallen waarin niet is voldaan aan het vereiste van directe confrontatie juist niet-ontvankelijkverklaring door de strafrechter volgt. ${ }^{51}$ Dit heeft verschillende gevolgen: na een nietontvankelijkverklaring kan de benadeelde partij immers de vordering aan de burgerlijke rechter in eerste aanleg voorleggen, terwijl men bij een afwijzing (en zonder hoger beroep in de strafzaak) nog slechts in een aantal gevallen - zo moet de vordering bijvoorbeeld de appelgrens overschrijden - zelf in beroep kan gaan bij de civiele rechter.

In de overige gevallen van afwijzing wordt niet duidelijk waarop de afwijzing door de rechter precies gebaseerd is, maar blijft het bij overwegingen dat niet is gebleken dat aan 'alle eisen' 52 of 'maatstaven die zijn tot stand gekomen in bestendige rechtspraak $^{\prime 53}$ voor vergoeding van shockschade is voldaan.

48. Zie bijv. Rb. Arnhem 8 december 2008, ECLI:NL:RBARN: 2008:BG6251: 'De rechtbank kan in deze strafrechtelijke procedure niet exact vaststellen welk bedrag aan vergoeding voor de geleden immateriële schade juist is.'

49. Zie over de rol van de strafrechter ten aanzien van de ontwikkelingen op het gebied van het smartengeld J. Candido \& S.D. Lindenbergh, Strafrechter en smartengeld, NTBR 2014/21, p. 173-179.

50. Rb. Zeeland-West-Brabant 19 mei 2014, NJFS 2014/154, Rb. Den Haag 25 juli 2013, ECLI:NL:RBDHA:2013:9145, Rb. Amsterdam 11 juli 2013, ECLI:NL:RBAMS:2013:4178, Rb. Amsterdam 21 mei 2012, NBSTRAF 2012/212, Rb. 's-Hertogenbosch 11 mei 2011, ECLI:NL:RBSHE:2011:BQ4001, Rb. Maastricht 13 februari 2009, ECLI:NL:RBMAA:2009:BH2772 en Rb. Limburg 24 november 2014, ECLI:NL:RBLIM:2014:10063.

51. Zie par. 4.1.

52. Rb. Zutphen 25 september 2012, JWR 2012/101.

53. Rb. Arnhem 21 april 2009, ECLI:NL:RBARN:2009:BI1700 en Rb. Arnhem 6 juli 2010, ECLI:NL:RBARN:2010:BN0299.

\section{Evaluatie}

Het voorgaande laat een aantal opvallendheden zien. Zo blijkt dat ongeveer een kwart van de gevoegde shockschadevorderingen geheel of gedeeltelijk wordt toegewezen in het strafproces; in de meeste gevallen worden benadeelden in hun shockschadevordering niet-ontvankelijk verklaard. De wijziging van het voegingscriterium per 1 januari 2011 lijkt hierin geen verandering te hebben gebracht. Voor zover benadeelden in hun shockschadevordering niet-ontvankelijk worden verklaard, is in de uitspraak niet altijd voldoende inzichtelijk gemotiveerd waarom dit in het concrete geval zo is. Meestal blijft het bij de vaststelling dat de behandeling van de shockschadevordering een onevenredige belasting van het strafproces vormt en/of dat een verklaring ontbreekt aan de hand waarvan het geestelijk letsel kan worden vastgesteld. In de gevallen waarin strafrechters shockschadevorderingen wel (deels) toewijzen, is in de meeste gevallen inderdaad een verklaring van een deskundige overgelegd. Hoewel in sommige gevallen de rechter het bestaan van geestelijk letsel zo evident achtte dat een nadere verklaring van een deskundige niet nodig zou zijn, blijkt deze 'souplesse' uiteindelijk in hoger beroep en/of cassatie geen stand te houden. Sommige strafrechters lijken terughoudend als het gaat om de omvang van het smartengeld, wijzen de vordering slechts gedeeltelijk toe (bij wijze van 'voorschot'), en verklaren de benadeelde voor het overige in hun vordering niet-ontvankelijk. Ook afwijzingen komen voor, voornamelijk wanneer aan het vereiste van directe confrontatie niet is voldaan.

Strafrechters lijken dus wel geneigd om een vordering tot vergoeding van shockschade in het strafproces toe te wijzen, zolang die vordering niet wordt betwist en wanneer het bestaan van geestelijk letsel is onderbouwd met een medische verklaring. Wanneer de omvang van het smartengeld een discussiepunt kan worden, zijn zij soms bereid om in elk geval een deel ervan toe te wijzen. Waar echter precies het 'omslagpunt' van de onevenredige belasting ligt, valt uit de rechtspraak niet duidelijk op te maken: de niet-ontvankelijkverklaringen worden niet uitgebreid gemotiveerd. ${ }^{54}$ Het is de vraag of dat wenselijk is, aangezien er voor de benadeelde veel op het spel kan staan (een niet-ontvankelijkverklaring zal in veel gevallen inhouden dat er geen schade wordt verhaald).

Het is de vraag of het wel steeds terecht is dat benadeelden met deze vorderingen een groot risico lopen op niet-ontvankelijkverklaring. Zeker als men in ogenschouw neemt dat met het verruimde voegingscriterium per januari 2011 werd beoogd te bewerkstelligen:

54. Zie V. Drost e.a., Wet versterking positie slachtoffers: procesevaluatie, Ministerie van Veiligheid en Justitie/DSP, september 2014, p. 33. Zij vermelden ook als knelpunt dat rechters over het algemeen onvoldoende motiveren waarom zij een vordering niet-ontvankelijk verklaren. Op zitting zouden zij dit doorgaans wel toelichten, maar deze onderbouwing wordt zelden opgenomen in het uitgeschreven vonnis. 
'(...) dat de strafrechter zoveel als mogelijk - en vaker dan nu het geval is - inhoudelijk over de vordering van de benadeelde partij beslist. Het enkele feit dat een vordering wordt betwist, niet onmiddellijk met voldoende bewijsmiddelen wordt onderbouwd of dat er bijvoorbeeld een enkele getuige of deskundige moet worden gehoord of het gevorderde bedrag hoger is dan gemiddeld, mag geen reden (meer) zijn de vordering om die reden niet-ontvankelijk te verklaren. Daartoe wordt voorgesteld het criterium "eenvoudig van aard" te vervangen door het strengere criterium "onevenredige belasting". Dat de omvang van de schade - ook immateriële - wellicht vaker dan nu het geval is zal worden bepaald door schatting, acht de indiener geen groot bezwaar. De voordelen voor het slachtoffer zijn immers groot.' 55

In dat licht is het opmerkelijk te noemen dat ten aanzien van shockschadevorderingen geen verschil waar te nemen valt tussen de situatie voor en na de verruiming van het voegingscriterium. Men zou juist een afname van het aantal niet-ontvankelijkverklaringen per 2011 mogen verwachten, en dus een relatieve toename van het aantal toe- en afwijzingen. Het is overigens in het algemeen niet duidelijk of het nieuwe voegingscriterium daadwerkelijk tot minder niet-ontvankelijkverklaringen heeft geleid: sommige professionals suggereren dat rechters het verruimde voegingscriterium in dezelfde mate en op dezelfde wijze hanteren als het 'oude' voegingscriterium. ${ }^{56}$ Mogelijk speelt hier het probleem dat niet duidelijk is hoe het begrip 'onevenredige belasting' moet worden begrepen. De behandeling van de gevoegde vordering moet kennelijk 'in een juiste verhouding' staan tot het eigenlijke strafproces, maar hoe moet men nu (op voorhand) bepalen of een nader onderzoek naar het bestaan van een in de psychiatrie erkend ziektebeeld wel of niet proportioneel is ? $^{27}$

Ook waar het de hoogte van het bedrag aan smartengeld betreft, voelt de strafrechter zich wellicht niet geheel 'thuis'. Of dat terecht is, is nog maar de vraag. $\mathrm{Nu}$ de rechter bij de begroting van het smartengeld moet letten op de bedragen die door Nederlandse rechters in vergelijkbare gevallen zijn toegekend, zou men kunnen zeggen dat het juist ten aanzien van shockschadevorderingen bij levensdelicten bij uitstek aan de strafrechter is om hier aanknopingspunten of zelfs een kader te ontwikkelen. Vereist is dan wel dat zij hun uitspraken meer uitgebreid motiveren dan zij nu doen. De uitspraken waarin strafrechters bij wijze van 'voorschot' een deel van het smartengeld (doorgaans $€$ 5.000) toewijzen en voor het overige de benadeelde niet-ontvankelijk verklaren, getuigen weliswaar van enige welwillendheid, maar vooral ook van de vrees om 'al te hoge bedragen' aan smartengeld toe te wijzen. ${ }^{58}$ Een discussie over de omvang van het 'volledige bedrag' aan smartengeld

55. Kamerstukken II 2007/08, 30143, 16, p. 1.

56. Zie Drost e.a. 2014, p. 33-34.

57. J. Candido e.a., Slachtoffer en de rechtspraak. Handleiding voor de strafrechtspraktijk, de Rechtspraak, december 2013, p. 133.

58. Candido e.a. 2013, p. 140. wegens shockschade mag ons inziens niet snel om deze reden als onevenredige belasting van het strafproces worden aangemerkt: dat lijkt immers haaks te staan op de bedoeling van de verruiming van het voegingscriterium in 2011.

\section{Slot}

Shockschadevorderingen kunnen ingewikkelde vragen oproepen, en dat is in het strafrecht - uiteraard - niet anders. Verschil tussen de strafrechtelijke en de civielrechtelijke route is dat de ingewikkeldheid in het eerste geval het risico van nietontvankelijkverklaring met zich brengt. Nu shockschadeproblematiek bij uitstek kan spelen bij levensdelicten, lijkt het ons zinnig dat ernaar wordt gestreefd deze vorderingen zo veel mogelijk binnen het strafproces te houden. Als de verruiming van het voegingscriterium serieus wordt genomen, als inzichtelijker wordt gemotiveerd waarom in concrete gevallen de behandeling van de vordering een onevenredige belasting van het strafgeding oplevert en als strafrechters niet beschroomd zouden zijn zich aan complexere civielrechtelijke (smartengeld)vorderingen te wagen, dan valt op dit terrein beslist winst te behalen. Nader onderzoek - ook in breder verband dan alleen ten aanzien van shockschadevorderingen - zal inzicht moeten verschaffen in de wijze waarop strafrechters zelf tegen deze problematiek en hun eigen rol en mogelijkheden hierin aankijken. 